Title: Murder by the book: using crime fiction as a bibliotherapeutic resource

Author: Liz Brewster

Postal address: Lancaster Medical School, Faculty of Health and Medicine, Lancaster University, Lancaster, LA1 4YW, UK.

Email: e.brewster@lancaster.ac.uk

Telephone: 01524595018

Keywords: reading, mental health, well-being, creative therapies, literature, crime fiction

Word count: 5311

Acknowledgments: The author thanks the participants in this research and Dr Barbara Sen and Dr Andrew Cox, Information School, University of Sheffield as PhD supervisors.

Competing interests: None declared.

Ethics approval: University of Sheffield Research Ethics Committee

Funding: The original study was funded by a University of Sheffield PhD studentship 


\title{
Murder by the book: using crime fiction as a bibliotherapeutic resource
}

\begin{abstract}
Crime is a popular genre of fiction, widely read but sometimes seen as 'throw-away'. Disregarding this type of fiction because it is seen as low-quality does not take into account its value to readers. Reading has been established as a means of improving mental health and well-being - often known as bibliotherapy. This often focuses on fiction considered to have literary merit rather than genre fiction like crime. However, in framing therapeutic reading in this way, the impact of texts considered to have low cultural value such as crime has been concealed. Examining reader responses as a starting point identifies some reasons why crime fiction fulfils a need. Readers in an empirical study spoke about the strong narrative as a distraction, the predictability as a comfort and the safe distance from events as a reassurance that left them feeling that reading crime fiction was a refuge from the world. In exploring reader responses in relation to the academic literature, the paper argues that there is a need to think differently about how readers engage with texts and how they experience reading as therapeutic, with a role for fiction like crime.
\end{abstract}




\section{Murder by the book: using crime fiction as a bibliotherapeutic resource}

\section{INTRODUCTION}

'The question is: why? What explains the extraordinary attraction of the crime novel? What basic psychological need, in tens of millions of people, did and does the detective story satisfy?"1

Crime fiction is a popular genre, and there has been longstanding interest in understanding what makes crime fiction so appealing to so many people. It is a diverse genre, but sometimes maligned as 'throw-away' fiction. ${ }^{2}$ This paper examines the attraction of crime fiction in relation to the therapeutic benefit of reading. In particular, there has been a focus on reading fiction considered to have high literary merit in some therapeutic reading schemes, with perceptions of crime leading to its exclusion. Inspired by findings from an empirical study, the paper outlines and explores why some readers consider reading crime fiction to enhance their well-being. It considers crime fiction as a case study for genre fiction, highlighting features of the genre that have previously not been considered therapeutic. Readers in the empirical study, who all struggled with mental health problems, commented that crime fiction made them feel safe and secure. The coexistence of mystery and familiarity facilitated improvements in well-being and helped in the recovery process. In examining this in more detail, the paper aims to highlight the complex relationship between readers, their lives and the text.

In engaging with the debates about low cultural value and popularity in relation to crime fiction, the paper argues that these debates have obscured some of the potential benefits of reading crime fiction. Although reading is seen as beneficial for mental health, often a quality judgment is placed on what literature is worth reading. ${ }^{3}$ Lists of texts marketed as 'mood boosting' books have been produced, which generally imply that such books need to be uplifting or humorous, thought-provoking and profound, or heart-warming to have a positive impact. ${ }^{4}$ This is not to say that great literature or inspiring works cannot have a positive impact; more that in framing therapeutic reading in this way, the impact of crime - and other texts considered to have low cultural value - has been concealed. Examining the academic literature on crime fiction in relation to readers' responses highlights these previously unrecognised effects on well-being.

\section{The popularity of crime}

Crime fiction owes a debt to the accounts of real life crimes that came before it in texts like the eighteenth-century The Newgate Calendar. ${ }^{5}$ Its longevity as a genre can be seen in the most recent British Library Public Lending Right figures (2014-15), which rank books borrowed from UK public libraries in order of popularity, and show that crime is still one of the most popular genres. Crime novels take fifteen of the top twenty 'most borrowed titles' places, and authors of crime fiction make up fourteen of the top twenty most borrowed authors in adult fiction. ${ }^{6}$ Research exploring reading preferences using the 2012 British Cohort Study data concluded that crime fiction was popular across all classes, with a tendency to be read more by the professional classes. ${ }^{7}$ 
As a genre, crime is diverse, but it has some recognisable conventions. Its appeal, in many respects, rests on the predictability of the genre. Contrarily, though predictable, stories are dissimilar with distinct characteristics. Crime fiction is also referred to as detective or mystery fiction, and has some elements in common with spy or thriller fiction. There is clear 'generic overlap' between novels that we refer to as crime fiction and those we do not. ${ }^{8}$ Lists of the best 100 crime novels $^{9}$ include texts as different as Raymond Chandler's hard-boiled detective in The Big Sleep, Frederick Forsyth's assassination-based thriller The Day of the Jackal and Edmund Crispin's comic crime novel The Moving Toyshop. Although there is a huge and varied range of settings, types and plots, there is some agreement about what essential elements a crime novel should contain. Toderov's typology outlined two basic types - the story of the crime and the story of the investigation ${ }^{10}$ - which can be manipulated to form a narrative that is both new and familiar. The reader has a fundamental understanding of what will happen, even though they may not have read the novel in question before. These 'rules' of crime and detective fiction have been increasingly prescribed and codified since the Victorian emergence of the genre, generally placed around 1841 (with Edgar Allen Poe's first detective - Dupin) and 1868 (with Wilkie Collins' The Moonstone as the first full-length detective novel).

The 'Golden Era' of crime fiction (predominantly the 1920s and 1930s) further typified the genre, with the Detection Club Oath stipulating that novels should adhere to the rule of 'fair play' and provide the reader with access to the same information as the detective solving the crime. ${ }^{10}$ These codifications enabled the reader to test their own abilities as a crime-solver. A key facet of the crime fiction genre was their resemblance to puzzles that needed to be solved. ${ }^{11}$ Codification leads, according to Barthes, to an established set of meanings which both confine expectations of the genre and define its appeal. ${ }^{12}$

Of the first ten Penguin Books titles published in the UK, two were crime fiction (authored by Dorothy L. Sayers and Agatha Christie), and over 700 titles were published under its 'green' crime imprint before 1970. Since its origins, crime and its subgenres have become increasingly diverse, including American noir, Scandicrime, historical crime fiction, modern forensic/ police dramas. But there is still an established set of meanings that provide the reader with an expectation of what they will encounter within the text. A familiar detective character will solve a crime and restore the world to a form of order. All parts of the story the hermeneutic code - will be explained. ${ }^{12}$ There will be no loose ends or enigmas by the end of the narrative. The predictability of the ending can be seen as formulaic, but it is readers' satisfaction in this closure, and their work in puzzling towards it, that account in some part for crime fiction's popularity - and sometimes to criticisms of its literary merit.

\section{Why has crime fiction not been valued?}

Genre fiction, including crime, has often not been seen as being of high value. While some texts are considered both literary fiction and crime fiction - like The Name of the Rose some crime fiction has been less well-received by literary critics. This paper does not aim to re-inforce these arguments, but to explore the relationship between high and low art. ${ }^{13}$ The relationship between great literature and popular fiction is complex, and has often placed a value judgement on what people should read or enjoy reading. One of the criterion used to ascertain quality has been its popular appeal - whether a book has a limited or mass readership. ${ }^{13}$ The differentiation between a 'good book' and a 'good read' affects readers' perceptions and lowers the merit seen in reading for pleasure. ${ }^{14}$ Escaping into a work of 
popular or genre fiction is not seen as a worthwhile activity on a level with engaging with one of the classics. Gold ${ }^{15}$ found that readers often do not talk about the reading they enjoy, because it is in conflict with notions of classical or great literature. 'Looking down' on crime as a mass market phenomenon associated with poor taste in literature has led to readers' unwillingness to publically acknowledge their love of non-literary fiction. ${ }^{16}$ When reading crime fiction is not seen as a legitimate pastime, this demonstrates that reading purely for the sake of enjoyment has been judged and found lacking.

Notions of a literary - or Western - canon are complex and there is no definitive list of works of 'great literature'. ${ }^{17}$ Nevertheless, the idea of canonical literature presents a powerful ideological critique of popular taste, leading to genre or formulaic fiction like crime being regarded as 'trash', or 'throwaway. ${ }^{2}$ Placing a value judgement on literature suggests that some titles are 'better' for the reader than others. Whether a text is seen as valued, legitimate or worthwhile affects the relationship between the reader and the text.

Recent research aiming to ascertain a relationship between reading fiction and improved theory of mind (a psychological concept associated with prosocial behaviours and empathy) highlights this further. ${ }^{18}$ Fiction is split into literary and genre fiction, with crime fiction placed firmly in genre fiction, concluding that only literary fiction is associated with improved theory of mind. The authors conclude that reading literary fiction might improve society. ${ }^{18}$

Judgements of taste are inherently linked to cultural capital. ${ }^{19}$ Popularity and commercial potential may be valued by publishers, but not by literary critics. Reading a piece of great literature should contribute to development and consciousness; reading a throwaway novel is time ill-spent. The assumption that taste needs to be 'elevated' to guide the reader on a path to self-improvement can be seen throughout the history of reading. ${ }^{16}$ In modern schemes aimed at engaging people with literature, a distinction is often made between the classics and other fiction. ${ }^{20}$ Reading certain books (including the classics) is still associated with symbolic mastery and increased cultural capital. ${ }^{7}$

The aim in highlighting these arguments is not to accept that crime fiction is a less worth reading than any other genre, but to demonstrate that while the value of crime fiction has been recognised by many academics and readers, there is still a reluctance to see most crime fiction titles as high art.

Crime fiction authors are often prolific, leading to series of books with the same characters, plot structure and tone. Series fiction - which does not have to be crime, but often is - has been much maligned as formulaic. Nevertheless, it has been established as a means of reading for pleasure. ${ }^{21}$ While it is seen as aesthetically lacking, it enables readers to read 'large quantities [of] texts that they enjoy. ${ }^{21}$ Series fiction has been justified as helping to improve literacy - although it has little cultural value, it is better than not engaging with reading at all. Others argue that reading series fiction lacks attainment and should not be encouraged, but it represents one way of reading that has value for readers and acknowledges that reading practices are not everywhere and always the same.

Reading crime fiction - with its best-selling, formulaic structure - is not seen as improving either the self or the literacy of the reader. Similar arguments have been made about the 'triviality' of reading romance novels, which have been compared with traditional fairy tales to demonstrate how aesthetic judgements are made. ${ }^{22}$ While reading romance novels is 
frowned upon, traditional fairy tales are seen as worthy of reading. Because of this, readers may still read romance or crime novels (because they enjoy them) but may not always disclose their enjoyment of them. The internalisation of these standards may lead to what has been called an 'aesthetic meta-response'. ${ }^{23}$ The judgement placed on an initial response to a text may be in conflict with the pleasure experienced in actually engaging with the text. While we may enjoy reading the book, we may not feel that enjoying it is appropriate.

However, as Rosenblatt ${ }^{24}$ argues: is there anything wrong with reading trash fiction if it is enjoyed by the reader? The pleasure associated with reading may serve other purposes than meeting distinctions of taste. The notion of 'guilty pleasures' has gained substance in modern Western culture. ${ }^{23}$ Access to cultural pursuits - music, film, television - that one enjoys but somehow feels one should not be engaging with again highlights the difference between a good book and a good read. Reading for pleasure is associated with frivolity and judged to be a waste of time, which has an impact on whether people view it as a worthwhile pursuit. ${ }^{25}$ From a therapeutic point of view, supporting people to find pleasure in an activity like reading can be seen as a recovery-focused outcome.

\section{Bibliotherapy: the therapeutic value of reading}

Nevertheless, the value of reading goes beyond aesthetic judgements about literature. There is an extensive and varied history of using reading to help people to manage mental and physical health problems. ${ }^{26}$ Reading - from poems to novels and non-fiction - is used to positive effect, particularly where people have poor well-being or diagnosed mental health conditions including depression and anxiety. This process has been called bibliotherapy, with diverse interpretations of what reading to improve health and well-being should involve. ${ }^{26}$ Evidence suggests that reading self-help literature may impact positively on mental health outcomes. ${ }^{27,28}$ Demonstrating the impact of reading fiction has been more difficult to achieve but an increasing body of evidence concludes that reading fiction has mental health and well-being benefits. ${ }^{3,20}$ Studies examining the impact of reading have often relied on experimental conditions or managed schemes rather than 'real-world' reading. ${ }^{29}$ This has meant that there has been an over-representation of texts selected by researchers and practitioners rather than readers in studies of the emotional and therapeutic impact of reading fiction. ${ }^{30}$ Although there is great interest in the effect of reading on neurological responses such as empathy and cognition, ${ }^{29,31}$ less work has been done with readers themselves examining responses to texts that they have chosen to read.

Several key studies have examined observed reading practices (asking readers what they read and what impact it had on them), concluding that reading is viewed positively and can comfort, inspire, provide validation of emotions and self-recognition, be cathartic and help to provide information to cope with life. ${ }^{32,33}$ Readers also found confirmation of thoughts and beliefs, reassurance and acceptance of their views in the fiction that they read. ${ }^{32,34}$ Finding a connection between personal experiences and those of characters in the book created a sense of connection that validated emotions. ${ }^{35}$ This sense of connection can be seen to be a value of the work of fiction, though this may lie in its verisimilitude, representing emotions and feelings, rather than its believability as a story that is true to life.$^{36}$ Readers identified that reading improved their mental and physical well-being by enabling them to relax. ${ }^{34}$ The sense of relaxation and connection felt by readers discussed in these studies shows that reading 'serves to satisfy a wide variety of needs. ${ }^{34}$ Enabling people to find pleasure in 
reading can be considered an outcome - as well as a process - of managing symptoms of poor mental health and well-being.

Interventions to harness the potential of reading to improve mental health and well-being can be found throughout the UK. ${ }^{4,37}$ The aim of these interventions is to bring together readers with texts that they may find restorative. This paper draws on this discussion of reading as an activity that has therapeutic benefit with readers' narratives of how reading crime fiction has had personal benefit for them. It concludes that making unsympathetic judgements about the quality of crime fiction does not take into account these benefits and potential uses.

\section{Some reflections on conducting the empirical study}

This paper is not solely a report of an empirical study; instead it uses findings from a broader study as an inspiration for further investigation of relevant literature and theory relating to reading and well-being. Before the data were collected, crime fiction had not been identified as a potential source of therapeutic benefit. Participants in the study discussed it spontaneously, and the relationship between the identified uses of crime fiction led to a theorisation that escapism, as typically understood, was not enough to fully explain why people saw crime fiction as a resource to help them manage their mental health problems. It is therefore relevant to briefly outline the methods of data collection to contextualise participant contributions, though the literature and empirical data will be considered together.

Interviews with people who identified reading as having a positive impact on their mental health were conducted as part of a the collection of a larger data set examining the provision of bibliotherapy schemes in public libraries, comparing policy aims with service user experiences. ${ }^{38}$ The empirical study aimed to examine individual experiences, with an awareness that each experience may be different ${ }^{39}$ within a framework of 'situated knowledges. ${ }^{40}$ Taking a constructionist approach justifies the methods of data collection used, aiming to access the many truths of reading and well-being via interviews, ethnographic observations and reflective analysis.

Participants volunteered to be interviewed in response to recruitment posters explaining the study placed in public libraries, and via articles written for local service magazines. A convenience sampling method was used, talking to all participants who volunteered to be interviewed. The focus of the interview was on reading and mental health, and participants were not asked to disclose a diagnosis or any details about medical treatment. However, many chose to discuss both in interviews, providing some context for their use of reading. All participants are referred to by pseudonyms, and minimal demographic data is provide to contextualise but preserve anonymity (box 1). 


\section{BOX 1: INTERVIEW PARTICIPANTS WHO DISCUSSED CRIME FICTION}

Alfie (late 40s, unemployed/ voluntary work). Alfie was diagnosed with schizophrenia and depression; he was a recovering alcoholic, and suffered from physical health problems. When he was depressed, or craving an alcoholic drink, reading helped him to focus away from these thoughts. Reading gave him a sense of achievement.

Milly (early 50s, unemployed/ voluntary work). Milly had suffered from several episodes of depression, and also spoke of her daughter's mental health problems. Milly had found reading and other creative therapies including knitting, to be invaluable in enabling her to maintain good mental health. She worked as a service user volunteer, helping to ensure the quality of mental health services in Smithville and was interested in using her experiences to make a difference to service provision.

Nathan (mid-50s, third sector). Nathan spoke of one major episode of depression, from which he was still recovering. Throughout his depressive episode, he had struggled with a variety of antidepressant medications, and accessed psychiatric support privately. His reaction to his diagnosis was to invest in academic texts on the treatment of depression, but he found himself unable to read any of them while ill. Instead, he read children's books and inter-war crime fiction.

Silas (late 30s, unemployed/ voluntary work). Silas had suffered from depression twice in his life, and was still recovering from the last episode, which had begun around four months prior to the interview. He was being treated using anti-depressant medication, and had self-referred to a local psychotherapy service. Silas had not spent much time reading before his depression, but now found benefit in reading crime thrillers to distract himself from his problems and reading for information about depression.

Winston (late 40s, self-employed). Winston was diagnosed with depression around fifteen years ago, and refers to his worst episode of the condition as a period of a few years in which he can remember very little. Winston had undertaken a course of anti-depressant medication and talking therapies during his depressive episode, but felt that the value of certain books had been of benefit to him, above that of other treatments.

\section{CRIME FICTION AND READERS' RESPONSES}

Despite the body of academic literature examining crime fiction and its merits, there is little evidence of why people actually do read crime fiction. Examining reader responses as a starting point identifies some reasons why crime fiction fulfils a need. Readers in the empirical study spoke about the strong narrative as a distraction, the predictability as a comfort and the safe distance from events as a reassurance that left them feeling that reading crime fiction was a refuge from the world. Taking this narrative further, questions of 'knowing and not-knowing' help to explore why some readers see reading crime fiction as having a positive impact on mental health and well-being and why it should be reconsidered as a potentially valuable literary resource.

\section{Escaping into crime fiction}

The escapist nature of crime fiction has been identified as part of its appeal, but also one of the reasons it has been denigrated as trivial or throw-away. ${ }^{1}$ Many pejorative judgements have been made about reading as a form of escapism, with its connections to fantasy and avoiding responsibility. ${ }^{14}$ In a therapeutic context, escapism has been seen particularly negatively, as a form of avoidance. However, it can be viewed more positively and framed as 
absorption or entrancement in a story - the idea of being 'wrapped up' in what is being read. ${ }^{14}$ Reading fiction to escape from the cares of the world can be 'more than merely a denial or retreat. ${ }^{34}$

Instead, escapist reading of crime fiction can be seen as a coping mechanism when readers are struggling to manage other aspects of their life. In the empirical study, Silas talked about the way that he had read several of Patricia Cornwell's forensic crime novels and referred to them as 'distraction therapy.' When discussing the benefits of reading for improving mental health, he considered reading these texts to be a form of treatment, helping him to avoid ruminating on the causes of his depression.

'I think what helps me with reading and being depressed is that you get absorbed in something and it takes your mind off other things. So certainly reading Cornwell, you can get so absorbed in that. So that's been a real benefit, that's enabled me to focus on that and then you tend not to think so much about why you're depressed.'

Avoidance of rumination can be seen as a constructive outcome of reading crime fiction and a positive element of escapism. One of the reasons Silas found these novels so compelling was because of their 'clear, strong story.' Although he had not been interested in reading before his recent depressive episode, he was now enthralled by these books; the last one I finished, I didn't want to finish it, because it was so good and so gripping. There's nothing worse than when you read a really good book and come to the end.' His comments again reflected the theme of the need to escape from the world and the idea of losing yourself in a good book. Milly expressed similar sentiments, noting that it was the strong narrative that made the experience more powerful.

'If my mood is low, I probably want something that's got quite a strong narrative. If I'm really stressed, nothing is better than crime fiction. There's a very strong narrative, obviously, with the cliff hangers [that] make you want to keep going.'

\section{Keeping a safe distance}

One of the inherent contradictions in suggesting that crime fiction can have a positive impact on mental health is the way in which crime itself is a negative experience. Violence and transgressions of societal norms can have a negative impact on well-being, and it seems counter-intuitive to suggest that reading about these events might be positive. Part of the enjoyment of crime fiction rests on the creation of a believable and realistic anxiety causing the reader to feel apprehensive about events. ${ }^{11}$ The heightening of feelings of unease and anxiety may suggest that actually, crime fiction should be avoided if the aim of reading is to improve mood and feelings of wellbeing. Three aspects from the empirical data and the academic literature help to explain this.

First, the idea of distance and safety, which can be a form of catharsis. Catharsis, the idea that reading a text can help to appropriately engage and regulate the emotions, has long been associated with the thought-provoking and insightful content of classical literature. In crime fiction, the very boundaried nature of the story provides a safe distance in which tragedies can be 'innocently witnessed." This distance can also be seen in the kind of crime fiction read at particular points. Turning to the empirical study, another participant, Nathan, 
sought solace in inter-war (Golden Age) detective fiction, such as Agatha Christie, Ngaio Marsh and Margery Allingham. In speaking about the reasons for reading these books, Nathan was very clear that the safety and security of reading these texts helped him to manage a serious episode of depression.

II read detective stories of the rather old-fashioned, very safe type. I think I wanted reassurance that there were boundaries. Despite the fact that somebody's been hideously murdered in the study, there is a safe boundary all around it and someone's going to come along and solve it.'

Nathan's experience was echoed by Milly, who felt that there were times in which reading challenging fiction was acceptable - and times when it was not.

'There are times, [like] when I was reading that Carole Shields book where you feel able to confront the nitty-gritty of life, as it were. But certainly with the older crime fiction, you don't have to. You can just get away with it'.

Second, there is a relative absence of violence in many crime fiction novels. The reader does not often bear witness to the violent act, and in some crime fiction, the body itself is relatively absent: the 'corpse-as-signifier. ${ }^{10} \mathrm{~A}$ crime has been committed because there is a body, but in itself, the body is more of a clue in the puzzle than anything more. Death is sanitised and not a central facet. In other examples of crime fiction, the murder weapons are in themselves a source of dark humour - consider Ngaio Marsh's novels, in which victims are dispatched in a bale of wool, with a jeroboam of champagne and a pistol hidden in a piano, for example."

Third, crime fiction offers a sense of closure. All crime novels end in the same way: the crime is solved; as McCracken states 'no detective story is complete without a solution.' 2 The solution should be a fair one: by a happy amateur using common sense and observation, or a professional investigator following procedure and carefully investigating the evidence, there is reassurance in the patterns and procedures - a 'social placebo' - that the crime will be solved. ${ }^{10} \mathrm{~A}$ book always has a beginning, middle, and an end. Leaving aside the chronology of events within the book, which may not always be linear, the sense-making of reading rests on peripeteia: the confidence in an end, with disconfirmation followed by a consonance. $^{41}$

The reader is given some level of agency, but even if they fail to correctly unravel the tangled web, there will still be a narrative resolution. These narrative conventions of crime, with its familiar journey from discovery of crime to its solution, can be seen as soothing. This process of solving provided some reassurance, as Milly commented in the empirical study.

'And also I think the predictability of it. Even though you don't know who did it, you know that you're going to go through a process and find out at the end who did, so it's quite comforting.'

Endings cannot always be said to be happy - in some novels, the perpetrator commits suicide rather than facing justice. But in some sense, the status quo is restored and life goes back to normal. This can be less true in modern forensic crime novels, in which the battered

\footnotetext{
* Died in the Wool, Vintage Murder and Overture to Death respectively.
} 
and bruised 'flawed' detective may learn a lesson about just how hard the world can be. However, this in itself is a lesson in resilience for the reader: no matter how terrible the crime and whatever the personal costs, some sense of order can still be restored.

\section{Repetition and familiarity}

The security and safety associated with reading crime fiction, as a genre, can be said to mirror the way in which young children interact with stories. Reading to pre-literate children often involves the repeated re-reading of the same text; 'the point of the favourite book... is that it remains the same. ${ }^{25}$ Even when the child can recite or read the story, the familiarity of a loved story provides routine and reassurance; what Nell refers to as 'endless repetition and undiminished enjoyment. ${ }^{14}$ In some ways, reading crime genre fiction represents a more sophisticated version of this practice. The reader is not re-reading the same story (and so there is an element of unfamiliarity and challenge) but they are reading a story with the same generic conventions. The idea of a 'new form of an old story' helps to establish expectations of the genre. ${ }^{2}$ In the empirical study, for Silas, the prolific nature of crime writers was also an important element of the experience.

'I think also, because she's written so many books, when you read the next one, you know the characters and it's just a kind of extension, a new story.'

Other participants, like Nathan, also spoke of reading 'voraciously' and 'obsessively' - one novel after another in the same genre. Sheldrick-Ross, in particular, has previously highlighted the way in which the familiarity of the outcome may create a level of reassurance in reading genre fiction such as crime..$^{21,42}$ This repetition could also be seen in the stories that participants in the empirical study chose to re-read. Winston spoke in detail about his 'little flock of books' which he read and re-read for reassurance and included, amongst others, the Sherlock Holmes novels and collected short stories.

'It's a set of stories that I read when I - not quite need cheering up, but just need a little bit of a reminder that it's maybe not all as bad as it could be... Sherlock Holmes, again, particularly short stories, and [those] that appeal to my intellectual point of view... the limits of what's possible [to understand] from logic and deduction.'

\section{DISCUSSION: KNOWING AND NOT KNOWING}

Readers talked about crime novels as a safe place to which they could escape when coping with their mental health problems was too much. The familiarity of crime fiction, in which some things are always the same but enough is different to keep the attention, was highlighted as a particular reason for reading. Calinescu ${ }^{43}$ identifies elements including foreknowledge and reassurance as elements of re-reading that can also be seen in the reading of crime fiction. The question of foreknowledge seems vital to the enjoyment of what happens in crime fiction; we beg other readers not to tell us how the story ends, but really we know already what happens. ${ }^{14}$ While a reader may mean 'don't tell me who committed the crime' - or how it was committed, in the case of locked room mysteries - they fundamentally know what will happen in the story. The familiar detective will use similar techniques to those he/she has used before to solve a mystery. The same supporting characters will be present - every Holmes has his Watson - and though the criminal will be different, with different motivations, there will still be a sense that someone has been brought to justice. In some 
texts, this will be bittersweet - perhaps the reader will sympathise with the criminal's motivations if not their actions.

One of the reasons that crime fiction may be of benefit to readers' mental health and wellbeing is the way in which the mysteries in crime fiction represent a solvable problem when solutions in wider life may not be found so easily. Part of the enjoyment here may be delayed gratification - the suspense of not yet knowing how the resolution will occur, but knowing that it will. ${ }^{5}$ This certainty means that it is possible to enjoy the uncertainty. This differs from life, in which the narrative is always and still emerging, and very little is certain.

Gold ${ }^{15}$ concludes that crime may be a popular choice of genre because it encourages problem solving and allows the reader to feel they are in control of the reading experience. Winston's comments about 'logic and deduction' from the empirical study mirror this - the reader and the detective are both given information to organise and interpret. This enables, as Porter states, the 'closure of the logio-temporal gap' between the crime in the past and its discovery and dénouement in the present. ${ }^{5}$

When asked about their mental health problems, people often discuss the experience of feeling powerless or out of control. ${ }^{44}$ If readers make a choice to read crime fiction, first, they have taken some control by making this choice. Second, they are provided with all the information required to organise and interpret a situation and be able to solve the puzzle, which may counter feelings of powerlessness. Third, they may be reassured by the straightforward way in which complex situations are managed by the detective; 'the obstacles placed in front of the characters are oversimplified. The ease with which problems are solved... probably constitutes one appeal. ${ }^{24}$ This may not be a realistic representation of life, but may still have verisimilitude for the reader.

Crime fiction may be popular because it is insubstantial and easy to read. ${ }^{5}$ But the arguments presented here identify something more to crime fiction that may be of benefit to people with mental health problems. If nothing else, this paper presents an argument for listening to readers' preferences about what they consider to be a therapeutic resource. Empowering readers to select texts they find restorative may have previously unrealised outcomes. This paper does not aim to give a conclusive answer to a question about what makes a good bibliotherapeutic resource. It draws on a small data set, which is a limitation, analysed in relation to the literature on crime fiction, to start to challenge established ideas about the value of popular fiction, particularly in a therapeutic context.

Thinking differently about how people read, engage with, and use fiction might help to identify diverse and previously unconsidered sources of support. What people actually value about the therapeutic benefit of reading is narrowly understood, potentially leading to a mismatch between current bibliotherapeutic interventions to help people to improve their well-being and what readers require. The arguments made here apply to other genre fiction; evidence from the empirical study ${ }^{38}$ also suggested that narrative non-fiction (popular science/ history, travel writing) and children's literature produced similar feelings of increased well-being. Crime fiction is used here as a case study to highlight one example of how thinking differently about genre fiction may increase our understanding of therapeutic reading. Further research with readers exploring their preferences may help to develop 
current interventions and identify new ways in which reading can be used as a supportive tool for mental health problems. 


\section{REFERENCES}

1 Mandel E. Delightful Murder: a social history of the crime story. London: Pluto Press 1984.

2 McCracken S. Pulp: Reading popular fiction. Manchester: Manchester University Press 1998.

3 Dowrick C, Billington J, Robinson J, et al. Get into Reading as an intervention for common mental health problems: exploring catalysts for change. Med Humanit 2012;38. doi:10.1136/medhum-2011-010083

4 The Reading Agency. Mood Boosting Books. 2016.http://reading-well.org.uk/

5 Porter D. The pursuit of crime : art and ideology in detective fiction. Ann Arbor, Mich. : UMI 1981.

6 Flood A. Crime fiction steals top slots in UK library loans. Guard.

2016.http://www.theguardian.com/books/2016/feb/05/fiction-runs-away-with-uklibrary-loans-lee-child

7 Atkinson W. The Structure of Literary Taste: Class, Gender and Reading in the UK. Cult Sociol 2016;10:247-66. doi:10.1177/1749975516639083

8 Rzepka CJ. Introduction: What Is Crime Fiction? In: Rzepka CJ, Horsley L, eds. $A$ Companion to Crime Fiction. Wiley Blackwell 2010. 1-9. doi:10.1002/9781444317916.ch

9 Moody S. Hatchards Crime Companion: The top 100 crime novels of all time selected by The Crime Writers Association. London: Hatchards 1990.

10 Scaggs J. Crime Fiction. Abingdon, Oxfordshire: Routledge 2005.

11 Asbee S. Margery Allingham and Reader Response. In: Bloom C, ed. TwentiethCentury Suspense: The Thriller Comes of Age. London: Palgrave Macmillan UK 1990. 161-73.

12 Barthes R. S/Z. London: Jonathan Cape 1970.

13 Black J. Crime Fiction and the Literary Canon. In: Rzepka CJ, Horsley L, eds. $A$ Companion to Crime Fiction. London: Wiley-Blackwell 2010. 76-89. doi:10.1002/9781444317916.ch5

14 Nell V. Lost in a book: the psychology of reading for pleasure. London: Yale University Press 1988.

15 Gold J. Read for your life: literature as a life support system. Markham: Fitzhenry and Whiteside 1990.

16 Furedi F. Power of Reading: From Socrates to Twitter. London: Bloomsbury 2015.

17 Bloom H. The Western Canon: the books and school of the ages. London: : Macmillan 1994.

18 Kidd D, Castano E. Different Stories: How Levels of Familiarity With Literary and Genre Fiction Relate to Mentalizing. Psychol Aesthetics, Creat Arts Published Online 
First: 2016. doi:http://dx.doi.org/10.1037/aca0000069

19 Bourdieu P. Distinction: A social critique of the judgement of taste. London: Routledge 1984.

20 Longden E, Davis $\mathrm{P}$, Billington J, et al. Shared Reading: assessing the intrinsic value of a literature-based health intervention. Med Humanit 2015;:1-8.

doi:10.1136/medhum-2015-010704

21 Sheldrick Ross C. 'If they read Nancy Drew, so what?' Series book readers talk back. Libr Inf Sci Res 1995;17:201-36. doi:10.1016/0740-8188(95)90046-2

22 Lee LJ. Guilty Pleasures: Reading Romance Novels as Reworked Fairy Tales. Marvels \& Tales 2008;22:52-66. doi:10.1353/mat.0.0045

23 Markowitz S. Guilty Pleasures: Aesthetic Meta-Response and Fiction. J Aesthet Art Crit 1992;50:307-16. doi:10.2307/431403

24 Rosenblatt LM. Literature as exploration. London: Heinemann 1970.

25 Meyer Spacks P. On Rereading. Boston: Belknap Press 2011.

26 Bate J, Schuman A. Books do furnish a mind: the art and science of bibliotherapy. Lancet 2016;387:742-3. doi:10.1016/S0140-6736(16)00337-8

27 Gellatly J, Bower P, Hennessy S, et al. What makes self help interventions effective in the management of depressive symptoms? Meta-analysis and meta-regression. Psychol Med 2007;37. doi:10.1017/S0033291707000062

28 Cuijpers $\mathrm{P}$, Smit F, Bohlmeijer E, et al. Efficacy of cognitive-behavioural therapy and other psychological treatments for adult depression: meta-analytic study of publication bias. Br J Psychiatry 2010;196:173-8. doi:10.1192/bjp.bp.109.066001

29 Bal PM, Veltkamp M. How does fiction reading influence empathy? An experimental investigation on the role of emotional transportation. PLoS One 2013;8:e55341. doi:10.1371/journal.pone.0055341

30 Oatley K. Such stuff as dreams: the psychology of fiction. Oxford: : Wiley-Blackwell 2011.

31 O'Sullivan N, Davis P, Billington J, et al. 'Shall I compare thee': The neural basis of literary awareness, and its benefits to cognition. Cortex 2015;73:144-57.

doi:10.1016/j.cortex.2015.08.014

32 Cohen L. Phenomenology of therapeutic reading with implications for research and practice of bibliotherapy. Arts Psychother 1994;21:37-44. doi:10.1016/01974556(94)90035-3

33 Gray E, Kiemle G, Davis P, et al. Making sense of mental health difficulties through live reading: an interpretative phenomenological analysis of the experience of being in a Reader Group. Arts Health 2015;3015:1-14. doi:10.1080/17533015.2015.1121883

34 Usherwood B, Toyne J. The value and impact of reading imaginative literature. $J$ Librariansh Inf Sci 2002;34:33-41. doi:10.1177/096100060203400104 
35 Toyne J, Usherwood B. Checking the Books: the value and impact of public library book reading. 2001.http://www.shef.ac.uk/content/1/c6/07/01/24/CPLIS - Checking the Books.pdf

36 Jones RA. Talking Brought Me Here": Affordances of Fiction for the Narrative Self. Theory Psychol 2010;20:549-

67.http://tap.sagepub.com/content/20/4/549.full.pdf+html

37 Hicks D, Creaser $\mathrm{C}$, Greenwood $\mathrm{H}$, et al. Public library activity in the areas of health and well-being: final report. 2010.http://research.mla.gov.uk/evidence/viewpublication. .php?dm=nrm\&pubid $=1068$

38 Brewster L. More benefit from a well-stocked library than a well-stocked pharmacy: How do readers use books as therapy? In: Rothbauer P, Skjerdingstad K., McKechnie EF, et al., eds. Plotting the Reading Experience: Theory/ Practice/ Politics. Waterloo, Ontario: : Wilfred Laurier University Press 2016. 167-82.

39 Denzin NK. Interpretive Interactionism. Thousand Oaks: Sage Publications 2001.

40 Mauthner NS, Doucet A. Reflection on a voice-centred relational method: analysing maternal and domestic voices. In: Ribbens J, Edwards R, eds. Feminist Dilemmas in Qualitative Research: public knowledge and private lives. London: Sage 1998.

$41 \quad$ Kermode F. The sense of an ending: studies in the theory of fiction. New York: Oxford University Press 1967.

42 Sheldrick Ross C. Reader on Top: Public Libraries, Pleasure Reading, and Models of Reading. Libr Trends 2009;57.http://hdl.handle.net/2142/13658

43 Calinescu M. Rereading. New Haven, CT: Yale University Press 1993.

44 Karp D. Speaking of Sadness: depression, disconnection and the meanings of illness. New York: : Oxford University Press 1996. 